\title{
FACTORS INFLUENCING THE POLICYHOLDERS FOR PREFERRING PRIVATE INSURANCE COMPANIES - A STUDY WITH REFERENCE TO CHENNAI CITY
}

\author{
P. Arul Minash Rajkumar1, Dr.N.Kannan², \\ ${ }^{1}$ Research Scholar, Sathyabama University, Chennai, 600119 \\ 2St.Mary's School of Management Studies, Chennai 600119 \\ paminesh@gmail.com, kannu74@yahoo.co.in
}

\section{INTRODUCTION}

The idea of insurance was conceptualized in the 12th century. Life is full of unexpected events that can change life forever. The concept has undergone several changes. Once it was viewed as the shelter to the family members. Later it has become a tax saving instrument than protecting the kith and kin. Compared to developed countries, the growth of insurance is not appreciable in India though there is wide scope. This millennium brought in marketable changes and the insurance corporations have to meet new challenges and competitors. There is abundant potential for insurance in India, so, the global players are playing a stiff competition.

Many private companies have ventured into the market. In this situation of eluded competition, the sector has come out with a variety of products for different segments of the society. So far the rural potential is uncared by this sector, some improvement is observed now. So far there was no option for the public in choosing the companies for their insurance products. The LIC was the monopoly in life insurance.

Now it is opened for the foreign tycoons that have ventured into the Indian market. It has become a common platform, as every insurance company has to compete with their innovating products, better service to serve within the market.

\section{CURRENT SCENARIO}

Currently there are 24 Life Insurance companies and 28 general insurance companies available in insurance market. According to S.B. Mathur, Chairman, LIC, this corporation is with the largest premium income of Rs. 11,565 crores during the current financial year and Rs. 100 crore exclusively for this year. Already established network is the main advantage for the corporation.
New India Assurance is a leading global insurance group serving the society with a network of 1112 officers. This is the only Indian insurance company, which has been rated "A" (Excellent) by A.M. Best Co., an international rating agency. The focus of coverage is mediclaim, personal accident, motor policy etc. The special feature is that the policy covers ten sections and the premium depends upon the number of sections opted.

India's life insurance segment collected new business premiums worth Rs 11,742.7 crore (US\$ 1.84 billion) for April-May 2013. Indian insurance companies collected a combined Rs 107,010.7 crore (US\$ 16.85 billion) worth of new premiums for $\mathrm{FY}$ 2012-13.

Meanwhile, the general insurance industry grew by 19.6 per cent in April-May period of FY 2013-14. Non-life insurers collected premiums worth Rs 13,552.46 crore (US\$ 2.13 billion) in the first two months of the current year, as compared to Rs $11,333.54$ crore (US\$ 1.78 billion) during the corresponding period of the previous year.

It is said that the insurance penetration had grown from 2.72 per cent in 2000 to nearly 4 per cent in 2013. Private insurance companies have reason to celebrate with the lifting of the sectoral cap in the insurance sector to 49 per cent as against 26 per cent earlier. Private companies like $\mathrm{ICICl}$ and Birla Sun Life are doing extraordinary performance in the industry.

$\mathrm{ICICI}$ is the private company, which touched Rs. 1000 crores premium income since it started operations in December 2000. In November 2004, it has crossed halfa-million number of policies. It concentrates on individual buyer for tax saving. It was found to be the most capitalefficient insurance companies. Shikha Sharma, M.D., $\mathrm{ICICl}$ Prudential Life Insurance Co., states that $\mathrm{ICICl}$ 
Prudential has persistently been maintaining its leadership position. The success of $\mathrm{ICICl}$ is based on the combination of reasons such as $\mathrm{ICICl}$ brand equity, distribution, services, products and a customer-centric approach. Unit linked policy is the most driving scheme contributing 87 per cent of its business. In December 2002, it started adopting six sigma quality programme for all customers facing process. Private insurance companies have done 12 per cent of the market share.

The next largest player is Birla Sun Life business worth about Rs. 164 crore. During the season of brinx sales, it reached around Rs. 450 crore this fiscal year. The forte is group insurance and it is doing remarkably well.

Bajaj Allianz's philosophy is to undust the customer's need, meeting customer's requirements, ensuring optimal coverage at lowest cost. In order to ensure speedy and accurate processing of needs, world-class technology with renowned insurance software and with networks in all offices. The unique risks covered are special insurance cover like Amarnath Yatras, Housing loans for people who are suddenly unemployed, covering home appliance, film insurance, ascent management cover, sports and entertainment insurance package.

Presently, Kotak Mahindra Life Insurance Ltd., is targeting a premium income of Rs. 300 crore for this fiscal year aiming at 2.5 times rise.

\section{VIEW ON FOREIGN INVESTMENT}

The hike in the insurance Foreign Direct Investment (FDI) limit to 49 per cent from 26 percent as per the announcement of Union Minister is felt that direct equity may result in hike of their share gradually. The M.D. of $\mathrm{ICICl}$ said it is advisable to bring in fresh capital instead of a direct swap.

Mr. Sandeep Bakshi of General Insurance Co., feels that foreign partnership enables expansion by providing increased access to insurance products to more people and to strengthen the distribution network.

But Mr. Naren N. Joshi, Chief Representative, ING Insurance International, expressed Indian partners would like to divert their stakes to foreign partners and use them far same other productive purpose because Indian partners are mostly hard-pressed far growth.
Antony Jacob, Royal Sundaram Alliance Insurance Ca. Ltd., expressed that increasing capital participation of internal insures will accelerate the development of Indian insurance companies through the development of technical competencies and innovative products.

Venkatesh, Managing Director, Metlife India Pvt. Ltd., views that it helps to increase the insurance penetration in the country. Faster growth rate brings mare products to suit rural people.

Aviva Life Insurance, M.D., Surart Purdy, expressed that currently out of Rs. 3179 crore capitalization of private life insurance companies, Rs. 827 crore is FDI. Foreign investment will help the customers to have a wider choice.

\section{PRODUCTS OFFERED}

The insurance companies offer multiple products with slight variation in their schemes. The products may be housing policy, health policy, automobile insurance, privacy policy, occasional investment insurance, life protection, children education policy, group insurance policy etc. The scheme of such policies is differentiated so as to compete in the market. The scheme may have a special feature to attract customers. Same schemes of special features are highlighted as follows.

Bajaj came out with an innovative scheme on householders, valued possession at home needs to be secured and the householders' insurance policy designed to cover various risks and contingencies faced by householders under a single policy protecting the members who permanently reside in the house and also the domestic and electric appliances.

Joint venture between Sundaram Finance of Chennai and Royal Sun Alliance of UK is built upon values of truth, trust, teamwork and professionalism. They believe the requisites for success are quality in service, transparency in transaction, outstanding customer care and an unyielding commitment. They concentrate on health products.

Export Credit Guarantee Corporation of India Ltd., offers private policy. The technical data or software which is provided to the website is protected against downloading or exposition of any software or technical data from the website to any jurisdiction prohibited by 
laws and regulations in force from time to time. Apart from routine schemes on shipment, the special schemes are transfer guarantee, overseas investment insurance and exchange fluctuations risk covers.

HDFC Life Insurance Policies are designed for people who wish to save life with extended security. The unique feature is that life protection continues for five years even after the payment of premium and the plan also participated in the profit. Through this he gets the full sum assured five years in advance and again at the end of the policy term. In addition to that for marginal additional premium, accident and critical illness benefit are also feasible. Apart from the routine schemes it also extends group term insurance policy, employees deposit linked insurance scheme, group gratuity plan etc.

Private insurance companies are confident that it is not the tax benefit alone that attracts customers. They believe best of courtesy, prompt service and high level of financial security as the other most important factors for the success of the business.

\section{RESEARCH METHOD}

Private Insurance companies are gaining their market share considerably in a very short tenure. Inspite of the good will, trust and established network of government corporations, this rapid change is observed in India. Private companies focus on friendly approach and better service. This paper aims at studying why the public mainly prefers private companies. The specific objectives of the study are stated below:

- To identify the reason for preferring private insurance companies

- To verify whether the preference varies between those who hold government insurance policies and those who do not possess.

- To understand the level of satisfaction relating to the different aspects of the private companies.

\section{Data Collection}

To collect the primary data to know about the views of the clients about various factors relating to the private insurance companies, a questionnaire is used to collect the data relevant to the objectives specified.

\section{Sampling Plan}

To study the aforementioned objectives, Chennai is chosen as the area of study. This city has mixed population where people from various states are residing. Based on the pre-test it is observed that the commonly known Private insurance companies are HDFC Life and $\mathrm{ICICl}$. Around 238 employees have purchased HDFC Life policies. Among them 50 respondents have been randomly chosen. The designed questionnaire has been distributed to the selected respondents; 41 have responded and one has been found to be invalid because it was incomplete. So 40 is the sample size representing around 15 per cent of the population.

\section{ANALYSIS}

The collected data have been analyzed using suitable statistical tools such as 't' test, ANOVA, Fredman's test and Factor Analysis and their performances are discussed as follows:

\section{Reason for Performance}

To identify the reasons for preferring a private insurance, thirteen statements have been prepared and the respondents' level of agreement was measured using five-point scale and the averages are shown in Table 1.

TABLE 1: Reasons for Preference

\begin{tabular}{|l|c|}
\hline Factors & $\begin{array}{c}\text { Average level of } \\
\text { agreement }\end{array}$ \\
\hline Less premium & 4.31 \\
\hline More return & 5.10 \\
\hline Attractive schemes & 6.51 \\
\hline Variety of products & 6.40 \\
\hline $\begin{array}{l}\text { Influence of friends/relatives as } \\
\text { agents }\end{array}$ & 7.53 \\
\hline Make a trial & 6.58 \\
\hline Better service & 8.89 \\
\hline Timely service & 8.90 \\
\hline Less formalities & 5.79 \\
\hline Better communication & 7.84 \\
\hline Trust worthy & 7.10 \\
\hline Friendly approach & 8.44 \\
\hline Immediate attention & 7.63 \\
\hline
\end{tabular}


The most important reasons for preferring private insurance company have been timely service, better service, friendly approach, better communication, immediate attention, influence of friends and relatives as agents and trust worthiness. The least important factor considered is the less premium level. The Fredman's test also confirmed that there is significant level of difference among the agreement level of the various factors listed at one per cent level. In view of these significant differences, non-parametric multiple comparison test has also been carried out to identify the order of priority. The first level of importance has been attached to the service factors such as friendly approach, better and timely service, the second order of reasoning for preference of private insurance goes to human relation factors such as better communication, trust worthiness, immediate attention and influence of friends and relatives as agents, the third to grouped factors which are almost product related ones such as attractive schemes and a variety of products, the fourth level of priority goes to economic factors such as less premium, more' returns and the least weighted factor is comfort oriented such as less formalities and attempting a trial.

\section{Reasoning and Demographic Factors}

Reasoning for opting private insurance has been grouped into five categories such as Service, Human relations, Economic, Product and Comfort. Statistical tests are used since these five groups differ based on the demographic factors such as age, gender and income.

\section{Table 2 : Age and Priority}

\begin{tabular}{|l|l|l|l|l|l|l|}
\hline Factors & & $\begin{array}{l}\text { Sum of } \\
\text { Sq. }\end{array}$ & df & $\begin{array}{l}\text { Mean } \\
\text { Sq. }\end{array}$ & F. & Sig. \\
\hline Service & B.G. & 4.507 & 2 & 2.253 & 1.149 & 0.328 \\
\hline & WG. & 72.593 & 37 & 1.962 & & \\
\hline H.R. & B.G. & 0.329 & 2 & 0.165 & 0.052 & 0.949 \\
\hline & WG. & 111.171 & 37 & 3.167 & & \\
\hline $\begin{array}{l}\text { Economi } \\
\text { c }\end{array}$ & B.G. & 15.949 & 2 & 7.974 & 4.762 & $0.015^{*}$ \\
\hline & W.G & 62.426 & 37 & 1.687 & & \\
\hline Product & B.G. & 6.028 & 2 & 3.014 & 1.631 & 0.209 \\
\hline & WG. & 68372 & 37 & 1.848 & & \\
\hline Comfort & B.G. & 4.729 & 2 & 2.365 & 0.577 & 0.567 \\
\hline & WG. & 151.671 & 37 & 4.099 & & \\
\hline
\end{tabular}

* Significant at 5 percent level

\section{Age}

To identify whether the reasoning level varies based on the three categories of the age group ANOVA has been applied and the result is shown in Table 2.

Priority towards economy related factors only varies significantly at five per cent level. From the mean values, it has been observed that aged people are more concerned about economic factors compared to the youngsters.

\section{Income}

Based on the income priority of the reasons for choosing private insurance do not vary significantly and is based on the income groups.

\section{Gender}

By applying ' $t$ ' test, an attempt has been made to study whether the priority of factors vary based on gender and it is observed that there is no significant level of variation in their priority based on gender.

\section{EXPERIENCE WITH PRIVATE INSURANCE}

ANOVA has been applied to study whether the priority for private insurance varies based on the experience with the private insurance. It has been observed that priority does not vary among the three categories of experience level of respondents.

\section{Government and Private Policy Holders}

To know whether the preference of private insurance varies between those who possess both government and private policies and private policy holders, 't' test has been applied and shown in Table.3.

TABLE 3 : Government and Private Sectors

\begin{tabular}{|l|l|l|l|}
\hline Factors & $\mathrm{t}$ & d.f & Sig \\
\hline Service & 0.644 & 38 & 0.523 \\
\hline H.R. & 0.732 & & 0.469 \\
\hline Economic & 0.191 & & 0.850 \\
\hline Product & 2.219 & & $0.033^{*}$ \\
\hline Comfort & 0.361 & & 0.720 \\
\hline
\end{tabular}

${ }^{*}$ Significant at 5 per cent level.

It could be observed from the result of the $t$ test that preference for private insurance varies between those 
who possess government policy and who do not possess relating to the factors such as attractive schemes and varied products. Comparing the mean scores of these two categories the respondents who have government policies express that the private insurance schemes are more attractive.

\section{Awareness}

The awareness about private insurance among the respondents are found to be mainly through the agents (42.5 per cent). The next important source of information is friends and relatives (35.0 per cent) and then advertisement (about 15.0 per cent). Employers of the private insurance and other sources have contributed only two and five per cent respectively in creating awareness.

\section{Recommendation}

The respondents' willingness to recommend private insurance to their close associates has been analyzed. 47.5 per cent of the respondents have expressed that they would surely recommend the private insurance policies to their close associates. Another 47.5 per cent are unable to decide and the remaining five per cent state that they would not recommend them to others.

\section{Willingness to OPT}

Among the respondents, 80 per cent prefer to take private insurance policy in the future and only 20 per cent say that they would opt for government policy.

TABLE 4 : Satisfaction Level

\begin{tabular}{|l|l|l|}
\hline \multirow{2}{*}{ Factors } & \multicolumn{2}{|l|}{ Satisfaction Level } \\
\cline { 2 - 3 } & Mean & S.D. \\
\hline Premium level & 3.8000 & 0.82275 \\
\hline Returns & 3.8000 & 0.72324 \\
\hline $\begin{array}{l}\text { Extension of } \\
\text { schemes }\end{array}$ & 3.7250 & 0.82694 \\
\hline Product variety & 3.9750 & 0.73336 \\
\hline Service extended & 4.2500 & 0.86972 \\
\hline Timely service & 4.2375 & 0.91978 \\
\hline Formalities & 3.9000 & 0.98189 \\
\hline Communication & 4.2750 & 0.71567 \\
\hline Worthiness & 3.8750 & 0.82236 \\
\hline Human approach & 4.1000 & 0.67178 \\
\hline $\begin{array}{l}\text { Immediate } \\
\text { attention }\end{array}$ & 4.0250 & 0.61966 \\
\hline
\end{tabular}

\section{Satisfaction}

Public have preference towards private insurance because of certain expectations. Their satisfaction towards eleven factors is given in Table 4, using a fivepoint scale.

The factors which highly satisfy the customers are communication, service extended, human approach, immediate attention and product available under less formalities. For these factors, even the variations among the respondents are less compared to other factors (Given in Table 5). So consistency is also observed in the level of satisfaction relating to these factors.

TABLE 5 : Percentage of Variance Accounted

\begin{tabular}{|l|l|l|l|}
\hline Factors & $\begin{array}{l}\text { Eigen } \\
\text { value }\end{array}$ & $\begin{array}{l}\text { Percenta } \\
\text { ge of } \\
\text { variance }\end{array}$ & $\begin{array}{l}\text { Cumul } \\
\text { ative } \\
\text { percen } \\
\text { tage }\end{array}$ \\
\hline $\begin{array}{l}\text { Premium } \\
\text { level }\end{array}$ & 3.359 & 21.311 & 21.311 \\
\hline Returns & 1.904 & 21.060 & 42.371 \\
\hline $\begin{array}{l}\text { Extension of } \\
\text { schemes }\end{array}$ & I. 732 & 18.641 & 60.012 \\
\hline $\begin{array}{l}\text { Product } \\
\text { variety }\end{array}$ & 1.241 & 14.859 & 74.871 \\
\hline $\begin{array}{l}\text { Service } \\
\text { extended }\end{array}$ & & & \\
\hline $\begin{array}{l}\text { Timely } \\
\text { service }\end{array}$ & & & \\
\hline Formalities & & & \\
\hline $\begin{array}{l}\text { Communicati } \\
\text { on }\end{array}$ & & & \\
\hline Worthiness & & & \\
\hline $\begin{array}{l}\text { Human } \\
\text { approach }\end{array}$ & & & \\
\hline $\begin{array}{l}\text { Immediate } \\
\text { attention }\end{array}$ & & & \\
\hline
\end{tabular}

Factor analysis has been carried out to identify the various dimensions of the satisfying factors. The percentage variance of the 11 factors has been carried at four factors having Eigen value greater than 1.0 are extracted. And the four factors have registered 74.87 per cent of variance of the factors considered for this study. Then the varimax factor loading is also worked out. 
The factors with high factor loading are service extended (0.848) timely service (0.749), product varieties (0.702) and extension of schemes (0.650). Based on this, the first factor identified was service and product. The second factor is supported by factor such as communication, worthiness and formalities with the corresponding factor loading of $0.884,0.765$ and 0.628 and may be grouped as comfort factors. The third factor grouped as economic factor which is supported by premium level and returns with the respective factor loading or 0.875 and 0.835 and finally the fourth factor is supported by immediate attention and human approach, which could be termed as human relations.

These four factors may be treated with demographic variables and the results are discussed below.

\section{Age and Satisfaction Level}

The satisfaction among respondents relating to service and product, comfort, economic and human relations factors are not found to vary significantly due to age.

\section{Gender and Satisfaction}

To identify whether there is any difference at the satisfaction level based on gender is studied using 't' test as shown in Table 6.

TABLE 6 : Gender and Satisfaction Level

\begin{tabular}{|c|c|c|c|}
\hline Factors & 't' & $\mathrm{df}$ & Sig. \\
\hline $\begin{array}{c}\text { Service and } \\
\text { product }\end{array}$ & -0.460 & 38 & 0.648 \\
\hline Comfort & -2.109 & & $0.042^{*}$ \\
\hline Economic & -0.536 & & 0.595 \\
\hline $\begin{array}{c}\text { Human } \\
\text { relations }\end{array}$ & -1.311 & & 0.198 \\
\hline
\end{tabular}

${ }^{*}$ Significant at 5 per cent level.

Comfort is the only factor, which varies significantly between male and female respondents. From the mean scores of the respondents, it is observed that female respondents are highly satisfied compared to male counterparts. Other factors do not vary significant based on gender.

\section{Experience and Satisfaction}

Experience of the respondents may also reflect on the satisfaction level. The result of the ANOVA is given in Table 7.

Table 7 : Experience and Satisfaction

\begin{tabular}{|l|l|l|l|l|l|}
\hline Factors & $\begin{array}{l}\text { Sum of } \\
\text { Sq. }\end{array}$ & d.f & $\begin{array}{l}\text { Mean } \\
\text { Sq. }\end{array}$ & F. & Sig. \\
\hline $\begin{array}{l}\text { Service and } \\
\text { product }\end{array}$ & 2.611 & 2 & 1.305 & 0.187 & 0.830 \\
\hline & 258.233 & 37 & & & \\
\hline Comfort & 43.932 & & 21.933 & 6.664 & $0.003^{\star}$ \\
\hline & 121.968 & & 3.296 & & \\
\hline Economic & 5.325 & & 2.662 & 1.443 & 0.249 \\
\hline & 68.275 & & 1.845 & & \\
\hline $\begin{array}{l}\text { Human } \\
\text { relations }\end{array}$ & 4.189 & & 2.094 & 1.678 & 0.201 \\
\hline & 46.186 & & 1.248 & & \\
\hline
\end{tabular}

* Significant at 5 per cent level.

Comfort is the factor which differs significantly based on experience. The mean scores indicate that the respondents below one year of experience have the highest level of satisfaction. This might be due to the fact that with the experience they get used to the facilities and so their satisfaction level may be low.

\section{Income and Satisfaction}

The result of the ANOVA indicates that the satisfaction level of the four factors such as product and service, comfort, economic and human relations do not vary significantly based on income level of the respondents.

TABLE 8 : Government and Private Sectors Policy Holders and Satisfaction

\begin{tabular}{|l|l|l|l|}
\hline Factors & 't' & d.f & Sig. \\
\hline $\begin{array}{l}\text { Service and } \\
\text { product }\end{array}$ & 1.189 & 38 & 0.242 \\
\hline Comfort & 0.087 & & 0.931 \\
\hline Economic & 1.628 & & 0.112 \\
\hline $\begin{array}{l}\text { Human } \\
\text { relations }\end{array}$ & 2.093 & & 0.043 \\
\hline
\end{tabular}

${ }^{*}$ Significant at 5 per cent level.

Government and private holders: In order to study whether the satisfaction level has differed among the 
respondents who hold both government and private policies and the respondents who hold only private policies, ' $t$ ' test has been made, as shown in Table.8.

A significant level of difference has been observed only relating to the factor human relations at 5 per cent level. The mean value score indicates that the respondents who hold government policies are found to have highly satisfied with human relations.

\section{FINDINGS}

Major findings of the study are:

1) Public prefer private insurance mainly for the reasons such as timely service, better service, friendly approach, better communication, immediate attention, influence of friends and relatives as agents and trust worthiness.

2) Aged people have more concern for economic factors compared to youngsters while studying the reasoning for private policy preference. All other factors like service, human relations, product and comfort do not vary significantly based on age though the reasoning levels are high.

3) Income, gender, experience with private insurance co., do not exert any significant level of difference relating to the factors like service, human relations, economic, comfort and product.

4) Respondents who are experiencing both private and government policies find that the private insurance schemes are more attractive.

5) The most important means of creating awareness are agents, friends, relatives and advertisement.

6) Only 47.5 per cent of the respondents are found to be willing to recommend private insurance but 80 per cent of them are willing to opt for private policies in the future.

7) Customers are found to be highly satisfied with service facilities, human relations and attractive schemes.

8) Age and income did not exert any significant level of difference in the satisfaction level of the customers regarding service, product, human relations, economic factors and comfort.
9) Female respondents are more satisfied with the comfort they experience in the private insurance company compared to male. Satisfaction relating to other service and products, economic and human relations does not vary based on gender.

10) Experience with the private insurance company also varies in the satisfaction level of comfort. Fresher's to private insurance found to be more comfortable than those who are more experienced. Satisfaction level does not vary relating to the factors such as services, economic and human relations factor based on experience with private insurance company.

11) Significant level of variation has not been observed in any differences relating to service and product, comfort, economic and human relations factors based on income.

12) Respondents who already possess insurance from government corporations are found to be highly satisfied with the human relation aspect compared to those who have only private insurance. This factor does not contribute much on service and product, economic and comfort aspects.

\section{SUGGESTIONS}

- Private insurance companies have gained their momentum by focusing on better service and relationship marketing. This advantageous position is to be further retained and product varieties can also be improved to attract male customers.

- When they plan schemes for different segments the elderly people scheme must focus more on economic factor because they attach more weightage to this factor compared to younger generation.

- Private insurance companies have attractive schemes to gain the attention of the public, it would be more effective if they could extend more varieties to attract.

- Though awareness level created by agents contribute much, it is necessary to increase the advertisement. This being new venture, its growth is based on the trust worthiness of the 
company but advertisement support is necessary till the agents gain values.

- Customers opt to buy private insurance policies in the future though all are not prepared to recommend them to others. Some motivational steps could be taken for the recommendations made by the customers.

- When female respondents are found to have a higher level of satisfaction relating to comfort, the advertisements can be focused on targeting the female in this aspect. Trial purchase is also a reason to a considerable extent. This might be based on brand loyalty. Companies must take steps to further improve the brand image through more advertisements and also maintaining their service level. Influence of friends and relatives as agents was found to be one of the most important factors influencing the clients in buying the policy and this is also supported by awareness factor. This source is to be highly exploited with rewards and recognition.

\section{CONCLUSION}

The Insurance industry is facing a healthy competition, which really benefits the public. Government sector should further improve their product varieties and attractive schemes to compete with the private sector and also change their attitude further towards service to survive in the market

\section{SCOPE FOR FURTHER STUDY}

This study is focused on HDFC LIFE alone and comparisons can be made with other private sectors. Region-wise comparison can also be made. Order of factors contributing to the- overall satisfaction of the clients can also be attempted. Defaults can be considered and the reasons for discontinuation may highlight the factors resulting in dissatisfaction.

\section{REFERENCES}

[1.] Insurance Chronicle, (October, 2002).

[2.] Opening the Insurance Industry-A Survey, Business World, (May, 1995).

[3.] Opening up Insurance Sector will Lower Premium Rate, The Financial Express, (February, 1996).

[4.] www.irdaindia.org/hist.htm. 